\title{
THE PLAKA PETRIFIED FOREST PARK IN WESTERN LESVOS - GREECE
}

\author{
Zouros N., ${ }^{1,3}$, Velitzelos E. ${ }^{2,3}$, Valiakos I. ${ }^{3,1}$, and Labaki . $^{1}$ \\ ${ }^{I}$ University of the Aegean, Department of Geography, GR - 81100, Greece \\ ${ }^{2}$ National and Kapodistrian University of Athens, Faculty of Geology and Geoenvironment, \\ Department of Hist. Geology - Paleontology GR - 15784Athens, Greece \\ ${ }^{3}$ Natural History Museum of the Lesvos Petrified Forest, Lesvos, GR - 81112, Greece
}

\begin{abstract}
On the island of Lesvos, large accumulations of fossilised tree trunks comprise the Lesvos Petrified Forest a protected natural monument. Within the protected area of the Lesvos Petrified Forest Geopark, several fossil sites with impressive fossilized trees have been discovered along the coast. During the last few years, the Natural History Museum of the Lesvos Petrified Forest has conducted systematic scientific research on these sites. The coastal area of Plaka was one of the main sites of research interest in order to explore the terrestrial and marine fossil sites. Several clusters of petrified trees have been found and identified in 45 different fossil sites. Some of them were standing while others were lying. The intact root systems of the standing trees provide proof that these trees were petrified in situ. Most of the trees are angiosperms and gymnosperms. The coastal landscape and its rich ecosystem, and the fossil sites, in combination with volcanic, tectonic and geomorphological structures, are basis of the rich geotouristic potential of the new Plaka Park, which has become an area for environmental education as well as a new geotouristic attraction.
\end{abstract}

Key words: geopark, fossil site conservation, geotourism.

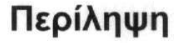

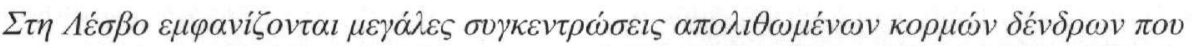

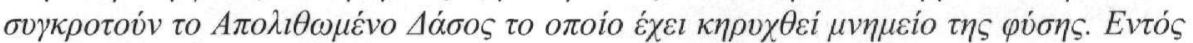

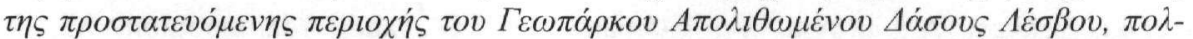

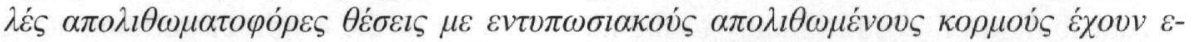

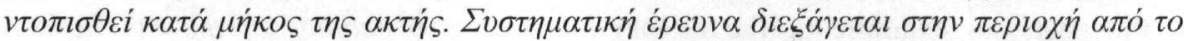

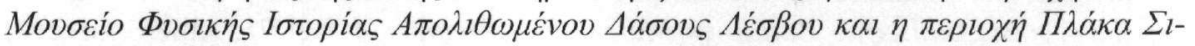

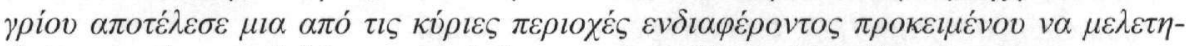

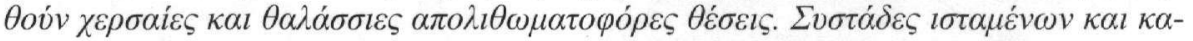

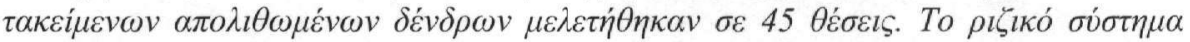

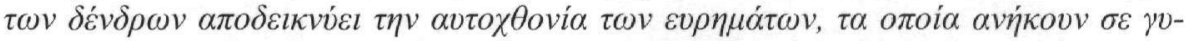

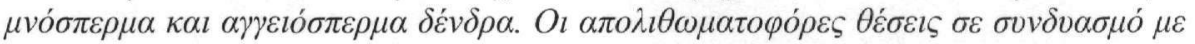

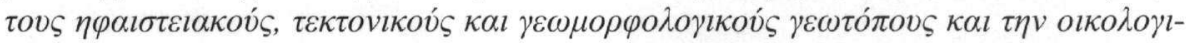

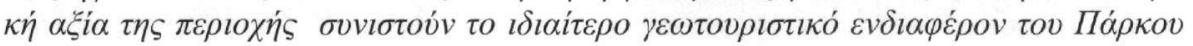




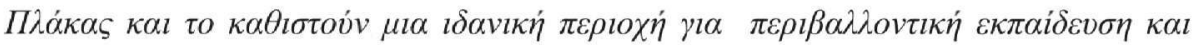
$\alpha v \alpha \psi v \chi \eta \dot{~}$.

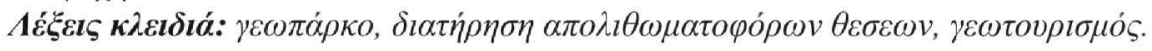

\section{Introduction}

The island of Lesvos is located in the northeast of the Aegean Sea and covers an area of 1630 square kilometres. Lesvos can be divided into four main physiographical regions: a. the southeastern part dominated by the Olympus mountain range which reaches a maximum height of 967 m. b. the Gulf of Kalloni grabben. c. the central mountainous region, which includes a chain of the main volcanic centres, extends from the western side of the Gulf of Kalloni to the northern shores of the island, hosting also the highest peak of the island, Lepetymnos $(968 \mathrm{~m})$. d. the hilly western part, dominated by pyroclastic formations and characterised by irregular peaks that reach heights of $600 \mathrm{~m}$.

The geological structure of the island is characterised by a basement of alpine and pre-alpine rocks which were covered later by post-alpine formations, mainly early Miocene volcanic rocks, which dominate the central and western part of the island, as well as Neogene marine and lacustrine deposits.

Lesvos is part of a belt of late Oligocene - middle Miocene calc-alcaline to shoshonitic volcanism of the northern and central Aegean Sea and western Anatolia (Fytikas et al. 1984, PePiper and Piper 2002). Regional neotectonic studies in the North Aegean conclude that Lesvos suffered at least three post-volcanic tectonic events since the Miocene. The broader region is characterized by basin and range topography (NE-SW and NW-SE) because of a prominent crustal extension and thinning (Mercier et al. 1989, Pavlides et al. 1990).

In the western part of Lesvos, large accumulations of exposed fossilised tree trunks comprise the Lesvos Petrified Forest, a protected natural monument.. The Lesvos Petrified Forest Geopark includes a core zone $(15,000$ hectares of the Petrified Forest protected area) and a broad buffer zone (more than 20,000 hectares of the central volcanic terrain). Within this vast area there are several fossil sites with exceptional concentrations of fossil plants. The main fossil sites are the Petrified Forest Park at the Bali Alonia site, the Sigri Park, the Plaka Park and the Nissiopi islet. Due to special protection and conservation measures, these areas are fenced and safeguarded, and visiting parks have been established (Velitzelos and Zouros 2006).

Systematic scientific research in the park has been carried out over the last decade by the Natural History Museum of the Lesvos Petrified Forest in collaboration with the Department of Historic Geology and Paleontology at the University of Athens. This research has focussed on better understanding the geological evolution of the island and the origin of the Petrified Forest. A number of geosites were identified, assessed, and mapped and a new geosite map of Lesvos was published (Fig. 1). Geosites within the Lesvos Petrified Forest Geopark, apart from the fossil sites, include volcanic geosites, stratigraphic geosites, tectonic geosites - active fault scarps, geothermal fields, karstic geosites and caves, erosional geosites (tafoni) and coastal and fluvial landforms (Zouros 2005).

\section{Volcanic activity and the formation of the Petrified Forest}

The formation of the Petrified Forest is directly related to the intense volcanic activity in Lesvos during early Miocene times. In the central part of the island there is a series of stratovolcanoes, situated along a SW-NE direction i.e. Lepetymnos, Vatoussa and Agra calderas. Impressive volcanic geosites are widespread all over western Lesvos (Fig. 1).

Vigorous volcanic activity in Lesvos was restricted to an almost two million year lasting period $(18,5-17 \mathrm{Ma})$. These volcanic rocks were shoshonitic with only minor interbedded calc-alcaline 
andesites (Pe-Piper and Piper 2002). Several volcanic rock units have been distinguished in Lesvos (Pe-Piper and Piper 1993). The Eressos formation is the oldest igneous formation, composed of porphyritic andesites interbedded with agglomerate and volcaniclastic rocks, and dated at $21.5 \mathrm{Ma}$. These lavas are 3 to $4 \mathrm{~m}$.y. older than the main volcanic sequence of Lesvos consisting of andesite lavas, dacite lavas and basalts, ingnimbrites and a thick pyroclastic sequence. The Sigri pyroclastics, densest in the west of the island, are connected with the development of the Lesvos Petrified Forest and are overlain by several sheets of the Polichnitos ignimbrite, dated around $17.0 \mathrm{~m}$.y. The Mytilene formation was defined by Pe-Piper $(1978,1980)$ as local basalt flows dated at 16.8 m.y. (Borsi, et al. 1972.). The Mesotopos dykes, dated by Pe-Piper (1978) at 16.2 m.y., are widespread throughout western Lesvos.

The fossilised tree trunks of the Petrified Forest appear within the thick Sigri pyloclastic sequence. This formation consists of several horizons of pyroclastic flows, mainly pumice flows, mud flows, debris flows and stream conglomerates intercalated with air fall pyroclastic deposits. Among them several siliceous paleosol horizons can be identified. In the Petrified Forest Park at the Bali Alonia site, flow directions in the pumice flows are indicated by the westward inclination of the standing petrified tree trunks as well as by damage to their eastern sides.

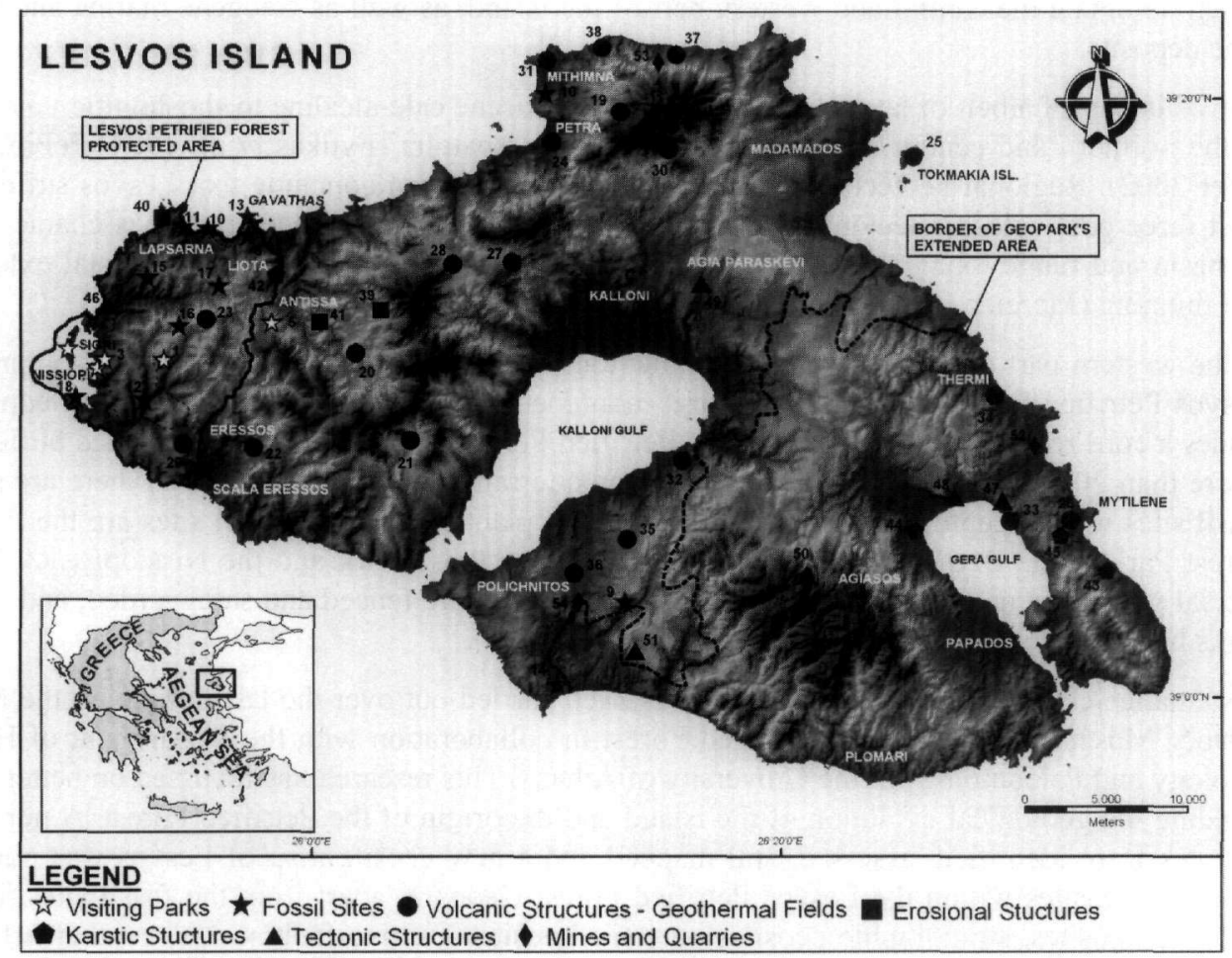

Figure 1 - Lesvos island with the main geosites, the Petrified Forest protected area and the extended Lesvos Petrified Forest Geopark boundaries (1=Petrified Forest Park, 4=Plaka Park, 29=Vatousa Kaldera)

Both pyroclastic and sedimentary rocks become coarser grained towards the Vatoussa volcanic center and interbedded lavas become more common, proving that the eruptive products derived from the caldera near the village of Vatoussa. This caldera shows wide spread alteration and mineralization.

Volcanic eruptions triggered pyroclastic flows which caused severe damage to the Miocene vegetation. The amount of erupted material was enormous. Magma intrusion caused the collapse of the western flank of the Vatoussa volcano in a debris avalanche, leaving a horseshoe - shaped caldera. 
The explosive phases seem to have been very strong, as is shown by the distribution of the eruptive products. The pumice phase was probably ejected to a great height before falling back on the volcano's flanks and surrounding area. An explosive blast of hot gases also traveled ahead of the debris avalanche, flattening thousands of trees which were covered later by pyroclastic materials. This caused the amputation of the majority of the trees one or two meters above the ground surface. Today the upper parts of the tree trunks are found horizontally, buried within pyroclastic layers. The comparable catastrophic 1980 eruption of the Mt. St. Helens volcano in the USA helps to understand the mechanism of the Vatoussa volcano eruption and give an idea about its effects.

The rapid covering of tree trunks, branches, and leaves led to their isolation from atmospheric conditions. Along with the volcanic activity, hot silica rich solutions penetrated and impregnated the volcanic materials that covered the tree trunks. Thus the major fossilisation process started with a molecule by molecule exchange of the chemical constituents of the organic plant into inorganic material (quartz) by keeping the tissue structures. In the case of the Petrified Forest of Lesvos, the fossilisation process was perfect due to favourable fossilisation conditions.

The study of the fossil tree trunks, leaves and seeds provides useful data about the palaeoflora, climate and relative age of the Lesvos Petrified Forest. In addition to the fossilised leaves, the genus or the species of the trees can also be determined by the micro-analysis of the internal structure of the fossilised wood. The palaeobotanical study of the fossils permits certain conclusions to be drawn on the composition of the forest which was dominated by higher plant groups such as angiosperms (flowering plants) and gymnosperms (conifers) with a low proportion of pteridophytes (ferns) (Suss and Velitzelos 1993, 1994, Velitzelos and Zouros 1997, 1998, 2000).

\section{Geology of the Plaka Park}

The Plaka peninsula is located in western Lesvos, within the Petrified Forest protected area, 500 $\mathrm{m}$. south of the village of Sigri. It is one of the main areas of research interest for exploring new terrestrial and marine fossil sites.

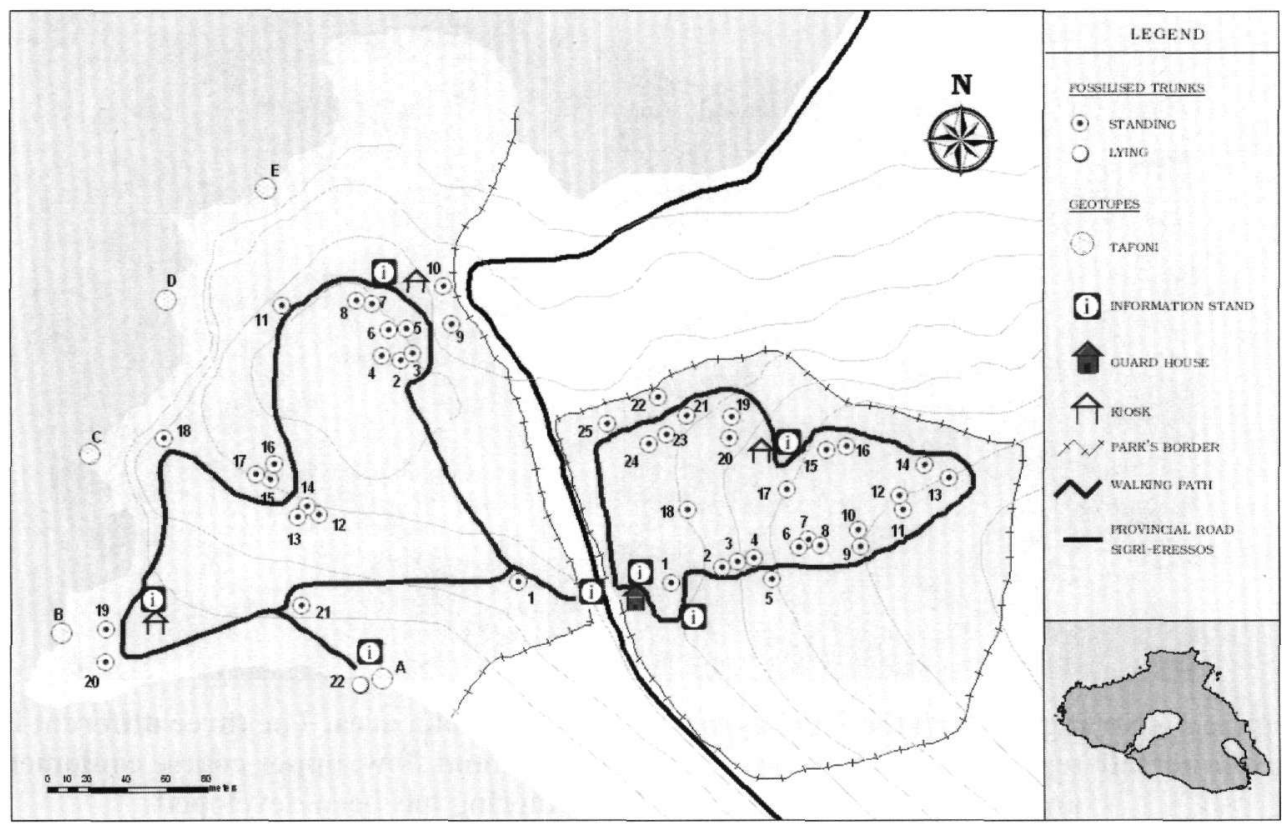

Figure 2 - The Plaka park map with the main fossil sites 
In the coastal area of Plaka, the Sigri pyroclastic formation consists principally of pumice flows, mud flows, debris flows and stream conglomerates intercalated with air fall pyroclastic deposits.

On western Lesvos, as in other volcanic areas, as loose slag and ash accumulate, plants grow preferentially in the erosion channels that develop on volcanic slopes. In these stream beds, plants are sheltered from the wind and can find water. When an eruption occurs, lava and pyroclastic flows or glowing avalanches tend to follow the existing drainage lines. Thus the vegetation concentrated in these channels is covered and incorporated into the debris.

According to their sediment facies, a sequence of pyroclastic layers appears repeatedly in the Plaka area. Within this sequence the following distinct layers can be determined as Plaka pyroclastics:

- An uppermost layer consists of coarse stream conglomerates, containing lava boulders, rounded to subangular cobbles of volcanic rocks and fragments of petrified tree trunks, in a fine-grained matrix of pyroclastics, strongly cemented by the circulation of silica rich solutions. This layer extends from 6-8 $\mathrm{m}$.

- An underlying mud flow layer. The debris carried in the flow contains pyroclastics, primary lava flow debris, pumice pieces and epiclastic material. The matrix consists mainly of finegrained ash. This layer is rich in fossil plants. This layer extends from 1,5 to $2 \mathrm{~m}$. but in certain sites can be even 4-5 m.

- The lower layer consists of fine-grained pyroclastic material and it is rich in coarse pumice debris. These are air fall pyroclastic deposits and their total thickness is less than $60-80 \mathrm{~cm}$. It is accepted that the tectonic regime affecting the North Aegean area is trans-tensional due to the presence of the North Anatolian - North Aegean trough Fault System (Pavlides et al. 1990). The post-volcanic intense neotectonic activity resulted in the creation of the main morphotectonic structures in western Lesvos.

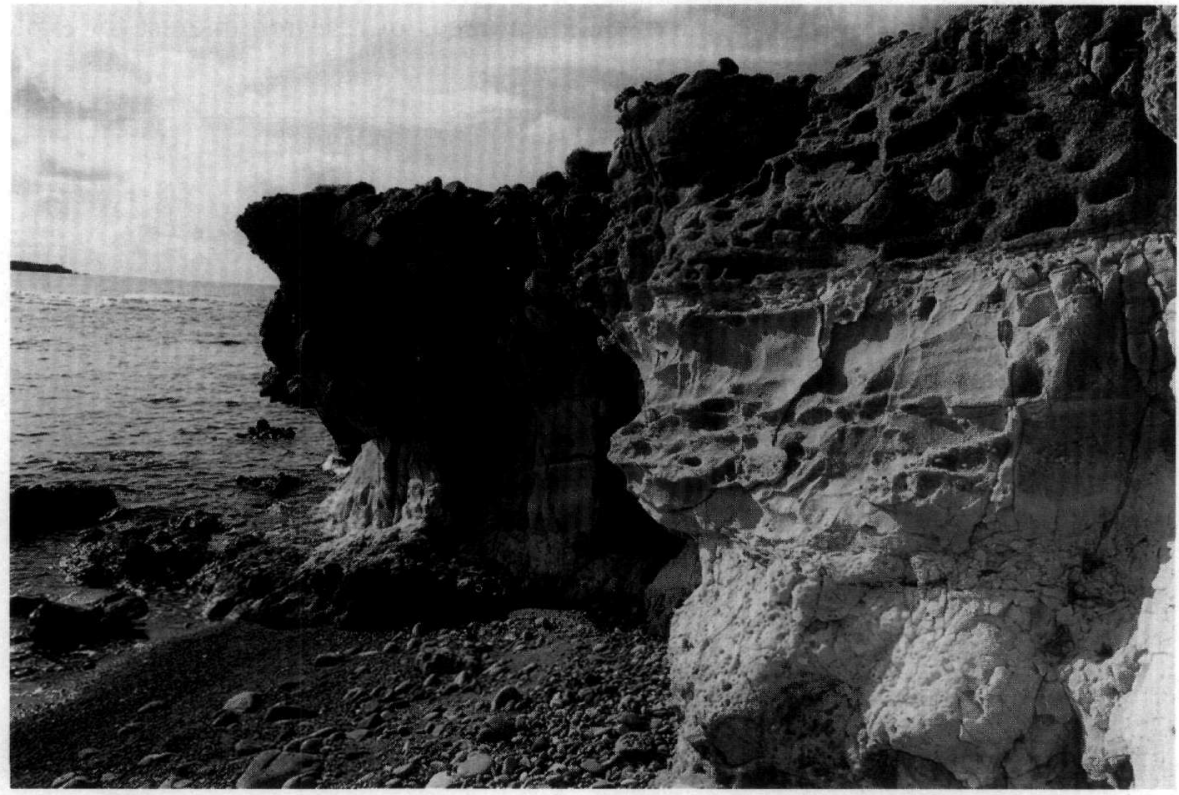

Figure 3 - Stratigraphy of the Sigri pyroclastics in the Plaka area. The three different layers (lower air fall tephra and pumice layer, intermediate mud flow, upper coarse conlomerates) are clearly visible. Honeycomb weathering has been developed

The neotectonic features in the study area can be classified into two main groups: E-W trending faults and N-S to NW-SE trending faults. These fault groups modified the local morphology, created a horst and graben relief, and shaped the Sigri area coastline. 


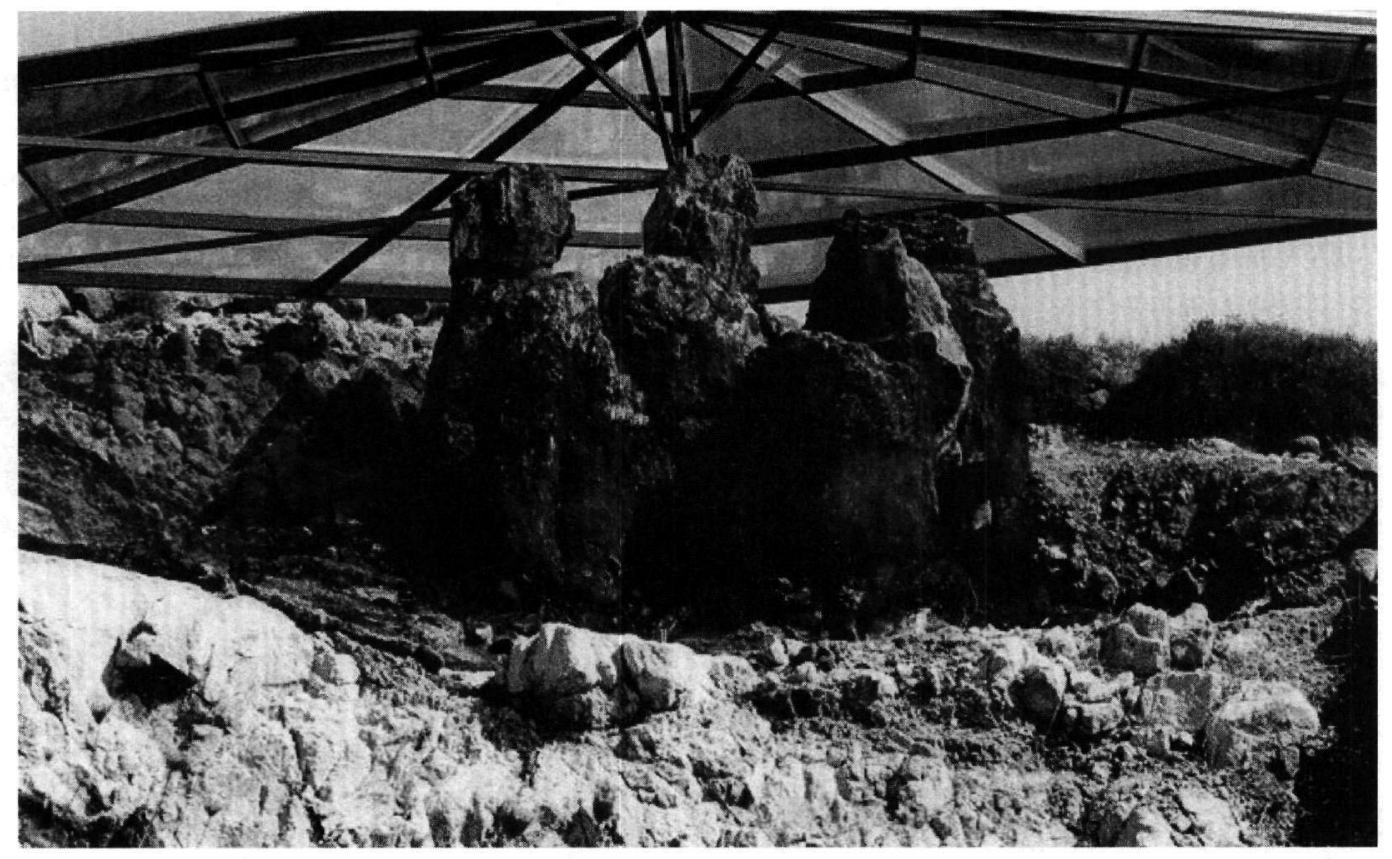

Figure 4 - Huge tree trunk of an angiosperm in the Plaka park (circumference of 13,7 m) which represents the Laurinoxylon sp.

As a result the area west of the Plaka peninsula coast was submerged and the petrified trees, already uncovered from their pyroclastic cover by continental erosion, were placed within a marine environment.

\section{The Plaka Petrified Forest park}

The decision to create a new visiting park in the Plaka area was stimulated by its abundance of standing and lying petrified tree trunks, the extraordinary high quality of findings in the area and the variation between the Plaka fossil site and the other fossil sites of the Lesvos Petrified Forest.

In 2000 the Greek State decided to concede an area of 7 hectares to the Museum for the creation of the Plaka Park, which now includes a marine and a terrestrial zone. The terrestrial zone is divided by the Sigri-Eressos road into two parts: the east and the west zone. The project was co-financed by the European Union and the Greek state.

Following detailed geological mapping and a geophysical survey, the Museum has carried out systematic excavation and conservation work since 2001 .

In both parts of the terrestrial zone of the Plaka Park, several clusters of petrified trees have been found and identified in 45 different fossil sites (Fig. 2). The majority of the petrified trees are standing while only few are lying. The diameters of the petrified tree trunks vary between 0,5 to 4,5 meters. Most of the trees are angiosperms or gymnosperms.

Among these trunks is the largest standing petrified tree trunk found in the Petrified Forest of Lesvos with a perimeter of $13.7 \mathrm{~m}$. (No1 East Plaka Park - Figure 4). This tree belongs to the Lauriaceae family and represents Laurinoxylon sp. (Velitzelos et al. 2006). It's root system both intact and in original position, providing proof that the tree was petrified in situ..

Many petrified tree trunks have been found also along the coast. The most spectacular trunk is the 14-meter long angiosperm (No 22 West Plaka Park - Fig. 5a). 
The palaeobotanic study of the findings indicate that several tree trunks and root knars belong to conifers (Pinuxylon paradoxum, Pinuxylon sp., Pinus sp.), angiosperms (Laurinoxylon sp., Populoxylon sp.) and monocotelydons (Parmoxylon sp.).

In the same pyroclastic fossiliferous layers many leaves, needles and cones have also been found which belong to the following families: Pinaceae (Pinus sp.), Lauraceae (Daphnogene polymorpha, Cinnamomum polymorphum), Fagaceae (Quercus sp.) as well as representatives of the pteridophytes (Pronephrium striacum) and the palmae (Phoenix sp.) (Velitzelos et al. 2006).
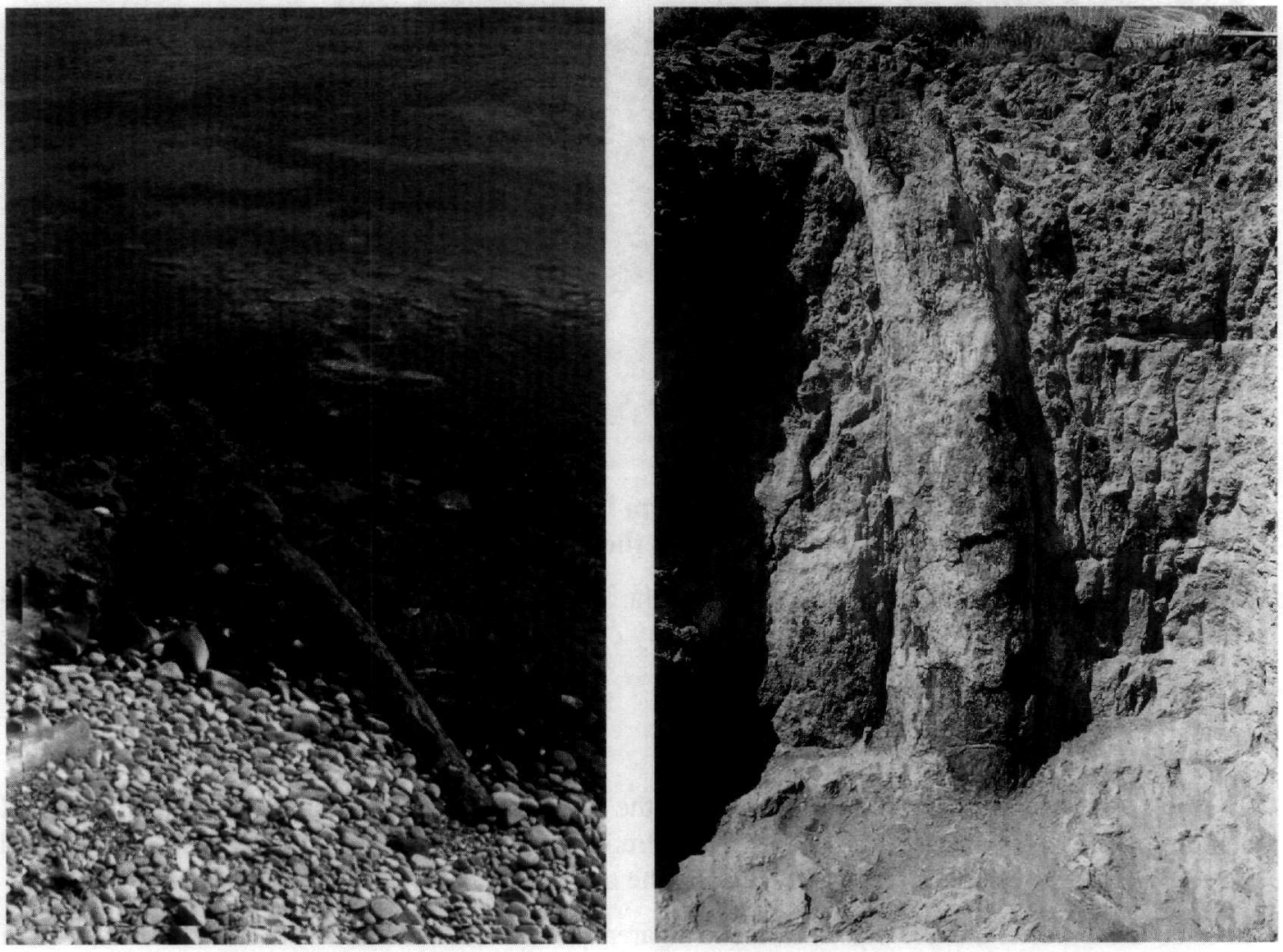

\section{Figure 5-14 meter long lying petrified trunk of an angiosperm tree (a) and a standing petri- fied trunk with morphological characteristics of Palmoxylon sp. (b) in the Plaka Park}

In the marine zone of the Plaka Park there are several fossil sites (Zouros et al. 2004). Some of the fossils are standing while others are lying on the today's sea bottom at a depth of $4-5 \mathrm{~m}$. The diameters of the petrified tree trunks in the marine fossil sites vary between 0,5 to $3 \mathrm{~m}$.

In the marine fossil site lying east of the Kavalouros islet, the root system of a conifer tree provides proof that fossil trees are lying in their original positions.

The importance of these findings is based on the fact that they reveal with greater certainty that the petrified forest of Lesvos is autochthonous due to the amount of tree trunks and root knars found intact. Another important fact is the fist appearance of reach clusters of Pinoxylon sp., the ancestor of the pine tree, in the mesophytic flora of the Lesvos Petrified Forest, identified by wood anatomy, foliage and seed cones.

The composition of the paleoflora in the Plaka fossil site shows a different character from other well-known fossil sites on Lesvos. In fact, based on the composition of the fossil plants, as in contemporary subtropical forest ecosystems we can distinguish different vegetation zones within the 
Miocene subtropical forest which has been preserved in the Lesvos Petrified Forest area. These zones become obvious when comparing the vegetation composition of the Petrified Forest Park and the Plaka Park.

In the Petrified Forest Park at «Bali Alonia» conifer trees dominated. In this area we can distinguish the Protopinaceae forest (the main representative being Pinoxylon paradoxum, SUSS and VELITZELOS) and the Taxodiaceae (sequoia) forest [the main representative being Taxodioxylon gypsaseum (GOPPERT) KRAUSEL and Taxodioxylon albertense (PENHALLOW) SHIKAMURA]. In lower relief areas, the coniferous tree forest is mixed with a deciduous forest (its main representative being Quercoxylon $\mathrm{sp}$.

At the Plaka Park, has been developed a vegetation zone with conifers (the main representative being Pinoxylon sp.) deciduous trees (the main representatives being Laurioxylon sp., Daphnogene polymorpha AL. BR., Cinnamomum polymorphum HEER sensu GRANGEON) and palms (the main representative being Palmoxylon sp. and Phoenicites sp.) which is characteristic of low altitudes.

This fact explains also the thick pyroclastic sequence present on the site, far away from the main volcanic craters of the island.

Apart from the fossil sites, the Plaka Park is characterized by unique volcanic, tectonic, erosional and coastal geosites. Along the coast there are spectacular tafoni structures. Tafoni are characteristic cavernous weathering features by sea water in various sizes and have arch shaped entrances, concave inner walls, overhanging margins and fairly smooth gently sloping, debris-covered floors (Fig. 6). They were developed mainly on the andesitic boulders of the Sigri pyroclastics (Gumus and Zouros 2006).

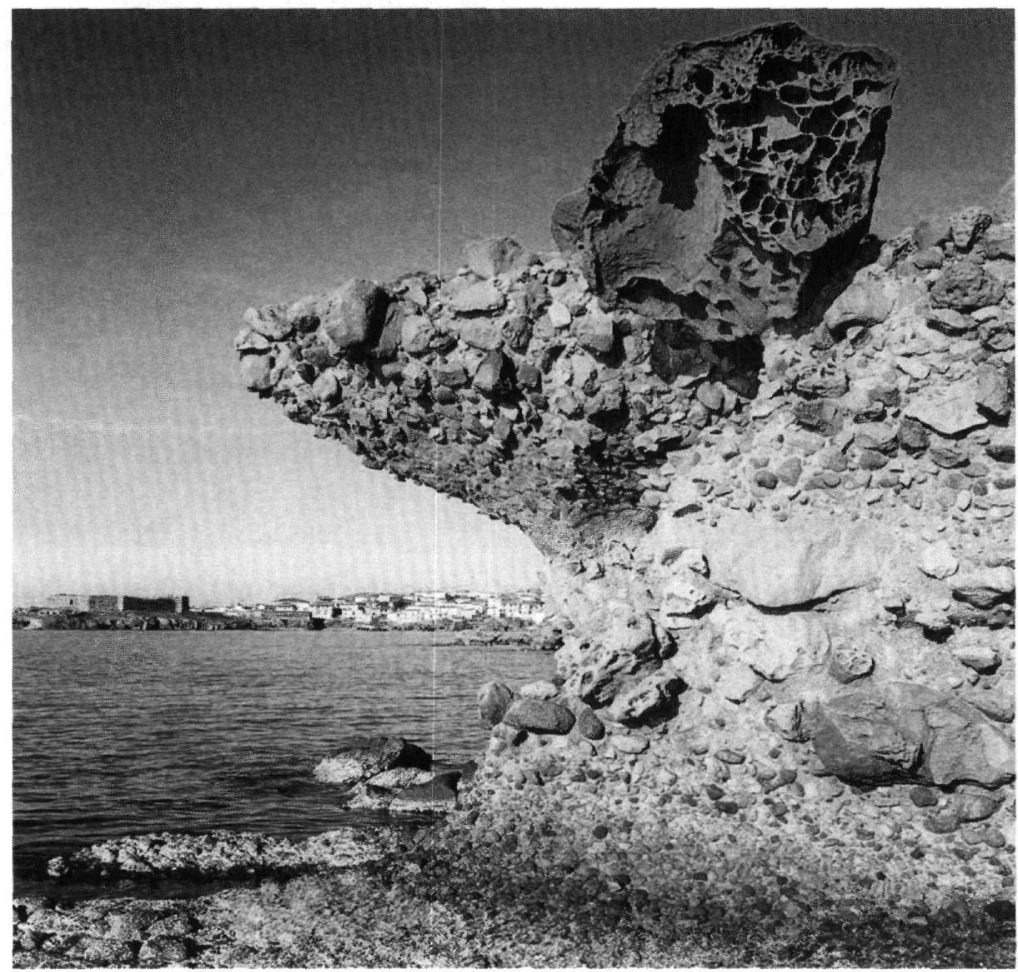

Figure 6 - An impressive tafoni structure at the top of a wave cut notch developed on the upper coarse grained layer of Sigri pyroclastics in Plaka park 
Fossil site conservation works have been carried out during the last four years in all fossil sites of the Plaka Park. Special shelters have been constructed in fossil sites facing major conservation difficulties. Small-scale interventions were also made in order to effectively conserve the fossil sites and to facilitate visitor access. These include the construction of protective low shelters, stonewalls and wooden fences along the trails that have been designed and built to guard the petrified trunks and protect them from run-off water and erosion, as well as cobblestone pathways and stone stairs that were carefully added to the trail system (Fig. 8).

Geosites of high scientific and educational value in combination with the unique landscape and a rich ecosystem comprise the rich touristic potential of the new Plaka Park. It provides an alternative visiting opportunity for tourists having already visited other fossil sites of the Lesvos Petrified Forest. It also has the potential to capture the interest of those who have little or no knowledge of earth sciences because of the unusual dimensions, objects and phenomena to observe and to discover. The park, accessible for older people and those facing mobility problems, is an ideal visiting site for families and children: a new geotouristic attraction.

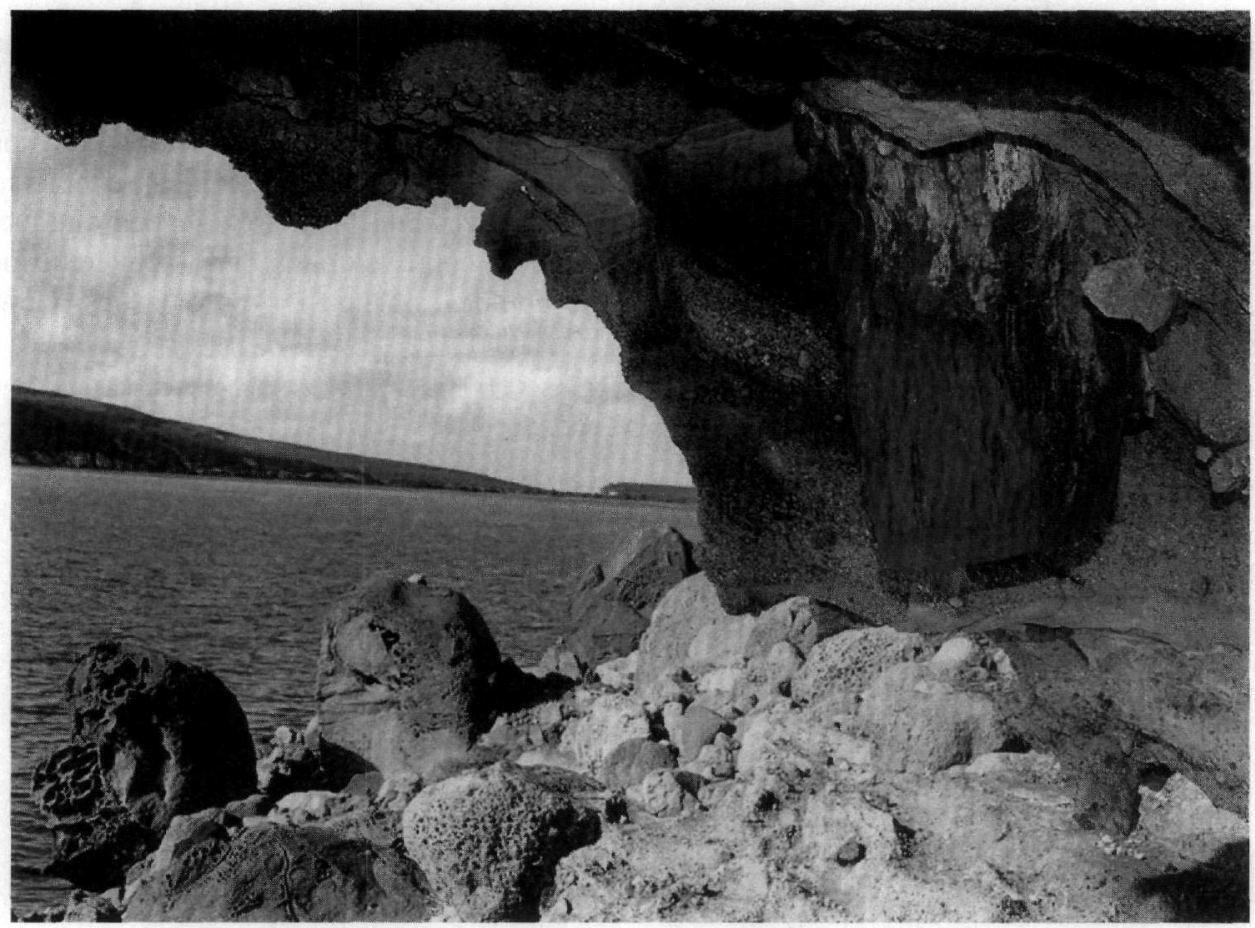

Figure 7 - Petrified tree trunk (up right) embedded in the Sigri pyroclastics. Tafoni structures (left) seen on the volcanic material in the Plaka Park

The Natural History Museum of the Lesvos Petrified Forest, operator of the Plaka Park since July 2005 , supports special guided tours in this area in collaboration with local tourist enterprises. The Museum has also created book-able educational programs to help students understand the importance of the Plaka fossil site which provides insights on the geological processes, the vegetation and the climatic conditions in the Aegean 20 million years ago.

\section{Conclusions}

Serious efforts have been made during the last decades to protect the Lesvos Petrified Forest and ensure its proper management. These efforts include scientific research, fossil conservation, the creation of the geosite inventory and map, the protection, interpretation, promotion and marketing of geosites, the creation of visiting parks, the foundation of the Natural History Museum of the 
Lesvos Petrified Forest, development of environmental education programmes, the establishment of a network of walking paths and eco-tourism infrastructure, organization of cultural events and promotion of the natural monument. All of these activities together form the main components of the Western Lesvos Geopark, a structure acting within the guidelines of geological heritage protection and sustainable local development.

The creation of the Plaka Petrified Forest Park is part of the management strategy for the Lesvos Petrified Forest. The scientific importance and research of this new fossil site is based on the presence of a vegetation zone which is different from the mixed conifer forest dominated by sequoias of the Lesvos Petrified Forest Park. The PlakaPetrified Forest Park vegetation zone consists of conifers, deciduous trees and palms, which are characteristic of a low altitude palaeo-relief.

This fact can also explain the presence of the thick pyroclastic sequence on site, far away from the main volcanic craters of the island, due to the huge mud flows which filled the paleo-valleys. Fossil site conservation efforts and geosite interpretation work, accompanied by the infrastructure and educational programs for visitors, have made the Plaka area a well-established new visiting park of the Petrified Forest of Lesvos, with a special geopotential to become a popular tourist attraction and an ideal location for discovery of the Earth history through environmental education activities.

The results of the identification, assessment, protection, promotion and management of geosites in the Plaka Petrified Forest Park which belongs to the Lesvos Petrified Forest Geopark show that Geoparks are an appropriate tool for heightening public awareness on the values of geological and geomorphological heritage.

The successful operation of such infrastructures will ensure the ongoing protection and promotion of the geological and geomorphological sites and bring significantly added value and benefit to local development.

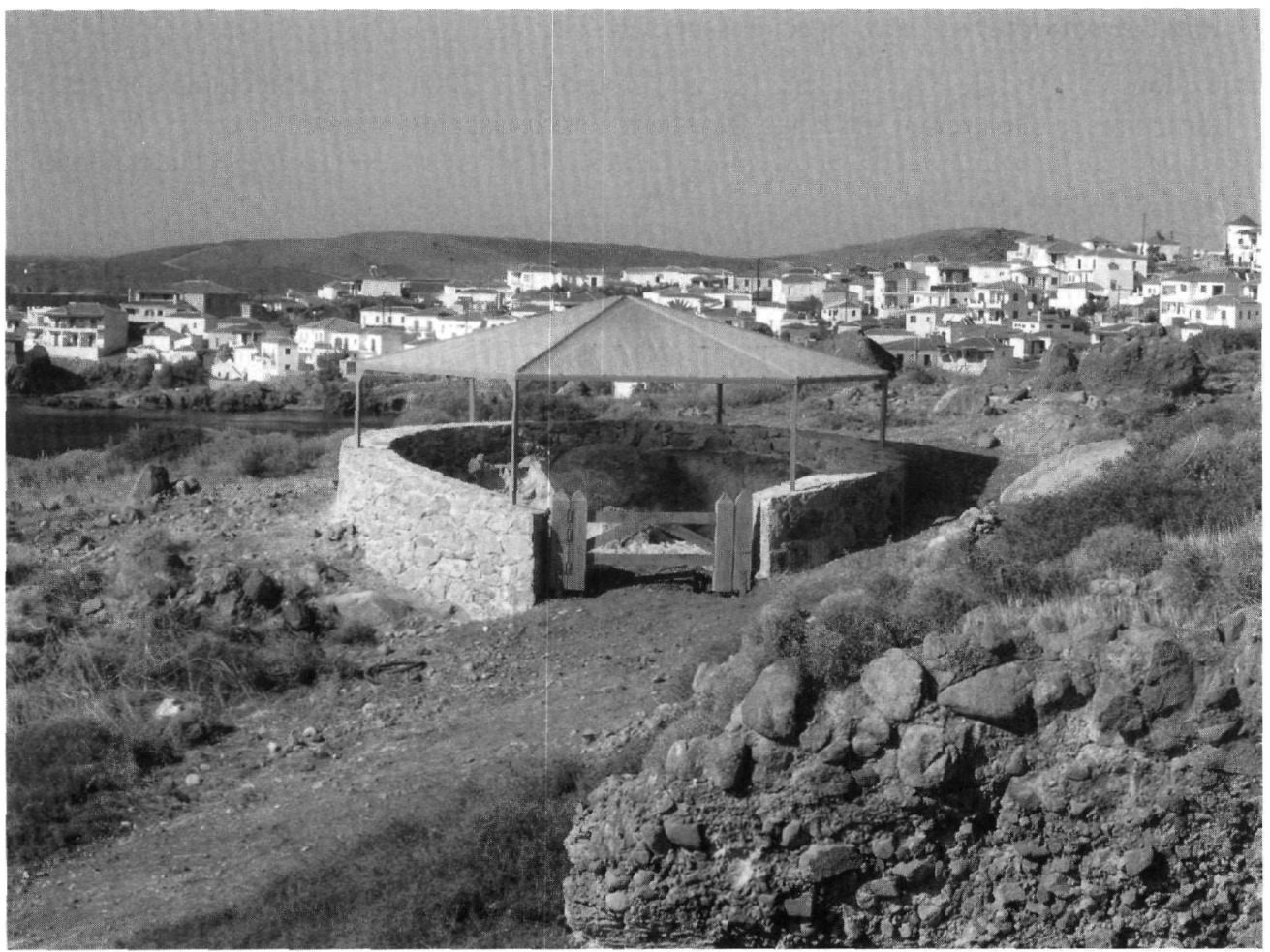

Figure 8 - Protective shelter in the Plaka park for a standing petrified tree trunk excavated within the coarse conglomerates layer of the Sigri pyroclastics formation 


\section{Acknowledgments}

This work has been carried out for the Natural History Museum of the Lesvos Petrified Forest with the financial support of the North Aegean Regional Operation Plan of the 3rd Community Support Framework (FEDER).

\section{References}

Borsi, S., Ferrara, G., Innocenti, F., and Mazzuoli, R., 1972. Geochronology and petrology of recent volcanics in the Eastern Sea (West Anatolia and Lesvos island), Bull. Volcanol., 36, 473-496.

Fytikas, M., Innocenti, F., Manetti, P., Mazzuoli, R., Perccerillo, A., and Vilari, L., 1984. Tertiary to Quaternary evolution of volcanism in the Aegean region, Geol. Soc. London, Spec. Publ., 17, 687-699.

Gropelli, G., Pasquare, G., Calvari, S., Carpa, L., Corazzato, C., De Beni, E., Diliberto, T., Marcias, J.L., Misuraca, A., Natoli, E., Norini, G., Tanner, L., Valiakos, I., and Zouros, N., 2001. Volcano flank collapse : the case of Etna volcano (Italy), Nevado de Toluca (Mexico), Lesvos (Greece), First International Workshop on Volcano-Basement interplay. UNESCO-IUGS-IGCP, Project No 455, 9-11.

Gumus, E., and Zouros, N., 2007. Cavernous weathering in Sigri area, Lesvos island Greece. (in press)

Katsikatsos, G., Migiros, G., Triantaphyllis, M., and Mettos, A. 1986 Geological structure of the internal Hellinides (East Thessaly - Southwest Macedonia, Euboea Attica Northern Cyclades Islands and Lesvos) Greek Institute of Geology and Mining Exploration, Geology and Geophysical research, Special issue, 191-212.

Mourouzidou, O., Pavlides, S., Fytikas, M., and Zouros, N., 2004. The neotectonic characteristic structures at the area of gavathas, Northern Lesvos island (Aegean, Greece), Proceedings of the 5th International Symposium on Eastern Mediterranean Geology, Thessaloniki 1419 April 2004. 861-864.

Pe-Piper, G., and Piper, D.J.W., 1993. Revised stratigraphy of the Miocene volcanic rocks of Lesvos, Greece. N. Jb. Geol. Palaeont., .M. 1993, 97-110.

Pe-Piper, G., and Piper, D.J.W., 2002. The igneous rocks of Greece. The anatomy of an orogen, Gebruder Borntraeger, Berlin, Stuttgart, 573pp.

Soulakellis, N., Novak, I., Zouros, N., Lowman, P., and Yates, J., 2006. Fusing Landsat-5/TM Imagery and shaded relief maps in tectonic and geomorphic maping: Lesvos island, Greece, Photogramatric Engineering \& Remote Sensing, 72(6), 693-700.

Suss, H., and Velitzelos, E., 1993. Eine neue Proto-Pinaceae der Formgattung Pinoxylon KNOWLTON emmend. READ, $P$. parenchymatosum sp. nov., aus tertiaren Schichten der Insel Limnos, Griechenland, Feddes Repertorium, 104, 335 - 341.

Suss, H., and Velitzelos, E., 1994a. Ein neues fossiles Koniferenholz, Taxoceoxylon biseriatum sp. nov., aus tertiaren Schichten der Insel Lesvos, Griechenland, Feddes Repertorium, 105, 5- 6, 257-269.

Suss, H., and Velitzelos, E., 1994b. Zwei neue tertiaere Hölzer der Gattung Pinoxylon KNOWLTON emend. READ aus dem Versteinerten Wald von Lesvos, Griechenland, Feddes Repertorium, Berlin, 105, 7 - 8, 403 - 423.

Velitzelos, E., 1993. Neue palaeofloristische Daten zu kainophytischen Floren Griechenlands, Doc. nat., 78, 1 - 17. 
Velitzelos, E., Petrescu, I., and Symeonidis, N., 1981a. Tertiaere Pflanzenreste von der aegaischen Insel Lesvos (Griechenland), Cour. Forsch. Inst. Senckenberg, 50, 49 - 50.

Velitzelos, E., Petrescu, I., and Symeonidis, N., 1981b. Tertiaere Pflanzenreste aus Agais. Die Makroflora der Insel Lesvos (Griechenland), Ann. Geol. Pays Hellen, 30, 500 - 514.

Velitzelos, E., and Symeonidis, N. 1978. Der verkieselte Wald von Lesbos (Griechenland) ein Naturschutzebiet, Vortrag - Kurzfassung beim Arbeitskreis Palaeobot., Palynol., 17, 19pp.

Velitzelos, E., and Gregor, H.-J., 1990. Some aspects of the neogene floral history in Greece, Rev. Paleobot. Palynol., 62, 291 - 307.

Velitzelos, E., and Zouros, N. ,1997. The Petrified forest of Lesvos - Protected Natural Monument. In Marinos, Koukis, Tsiambaos and Stournaras (eds), Engineering Geology and the Environment, Balkema, 3037-3043pp.

Velitzelos, E., and Zouros, N., 1998 New results on the petrified forest of Lesvos, Bulletin of the Geological Society of Greece, 32/2, 133-142.

Velitzelos, E., Suss, H., Kvatcek, Z., Gregor, H.-J., Iamandei, S., Iamandei, E., Velitzelos, D., and Konstandopoulos, K., 2006. Identification of the Plaka park fossils in Sigri, Lesvos isl., Unpublished report. University of Athens. $47 \mathrm{p}$.

Velitzelos, E., and Zouros, N., 2006. The petrified forest of Lesvos, Topio publications, Athens, $160 \mathrm{pp}$.

Zouros, N., 2005. Assessment, protection and promotion of geomorphological and geological sites in the Aegean area, Greece, Géomorphologie: relief, processus, environnement, no 3, 227 234.

Zouros, N., Velitzelos, E., Valiakos, E., and Ververis, K., 2004. Submarine petrified forest in Lesvos Greece, Proceedings of the 5th International Symposium on Eastern Mediterranean Geology. Thessaloniki 14-19 April 2004 437-440pp. 